\title{
Human T cells employ conserved AU-rich elements to fine-tune IFN- $\gamma$ production
}

Julian J. Freen-van Heeren ${ }^{*}$, , Branka Popović, ${ }^{* \dagger}$, Aurélie Guislain ${ }^{*}$, , and Monika C. Wolkers ${ }^{*},+\$$

Author Affiliations

* Sanquin Research-Amsterdam UMC Landsteiner Laboratory, Department of Hematopoiesis and Oncode Institute, Amsterdam, The Netherlands.

Contact details

Correspondence to: Monika Wolkers. Department of Hematopoiesis, Sanquin Research-AMC Landsteiner Laboratory, Plesmanlaan 125, 1066 CX Amsterdam, The Netherlands. email: m.wolkers@sanquin.nl. 


\begin{abstract}
Long-lasting $\mathrm{CD}^{+} \mathrm{T}$ cell responses are critical in combatting infections and tumors. The proinflammatory cytokine IFN- $\gamma$ is a key effector molecule herein. We recently showed that in murine $\mathrm{T}$ cells, the production of IFN- $\gamma$ is tightly regulated through AU-rich elements (AREs) that are located in the 3' Untranslated Region (UTR). Loss of AREs resulted in prolonged cytokine production in activated $\mathrm{T}$ cells and boosted anti-tumoral $\mathrm{T}$ cell responses. Here, we investigated whether these findings can be translated to primary human $\mathrm{T}$ cells. Utilizing CRISPR-Cas9 technology, we deleted the ARE region from the IFNG 3'UTR in peripheral blood-derived human $\mathrm{T}$ cells. Loss of AREs stabilized the IFNG mRNA in T cells and supported a higher proportion of sustained IFN- $\gamma$ protein-producing T cells. Importantly, this was also true for tumor antigen-specific T cells. MART-1 TCR engineered T cells that were gene-edited for ARE-deletion showed increased percentages of IFN- $\gamma$ producing MART-1specific ARE-Del T cells in response to MART-1 expressing tumor cells. Combined, our study reveals that ARE-mediated post-transcriptional regulation is highly conserved between murine and human $\mathrm{T}$ cells. Furthermore, generating antigen-specific ARE-Del $\mathrm{T}$ cells is feasible, a feature that could potentially be exploited for therapeutical purposes.
\end{abstract}

Keywords: $\mathrm{T}$ cells, cytokine production, IFN- $\gamma$, post-transcriptional regulation, AU-rich elements. 


\section{INTRODUCTION}

$\mathrm{CD}^{+} \mathrm{T}$ cells are critical for immunosurveillance and for the protection against invading pathogens. To do so, they produce effector molecules, including granzymes, chemokines, and cytokines. Interferon $\gamma(\mathrm{IFN}-\gamma)$ is a key cytokine for $\mathrm{CD}^{+} \mathrm{T}$ cells to exert their effector function [1]-[3]. IFN- $\gamma$ is a pleiotropic cytokine that modulates angiogenesis, hematopoiesis, myelopoiesis and immune cell function [4]-[7]. During infections, IFN- $\gamma$ can suppress the growth of pathogens through upregulation of antiviral factors [8], and attract myeloid cells such as neutrophils to the site of infection [9],[10]. Furthermore, IFN- $\gamma$ sensing potentiates the innate immune response of dendritic cells, macrophages, monocytes and neutrophils to pathogens against (intra)cellular pathogens [9]-[13]. Indeed, point mutations and deletions in humans in the receptor for IFN- $\gamma, I F N G R I$ and IFNGR2, which often lead to premature stop codons, revealed that IFN- $\gamma$ sensing is instrumental to protect the host from infections by Mycobacteria species [14]-[16].

IFN- $\gamma$ also prevents the development of cancers. In fact, mice lacking the Ifng gene, or the signaling protein downstream of Ifngr1/2, Stat1, spontaneously develop tumors [17],[18]. Furthermore, a high IFNG-mediated gene signature correlates with clinical response rates to immunotherapy in humans [19],[20]. Conversely, copy number alterations of IFN- $\gamma$ pathway genes correlates with poor response to immunotherapy [21].

The regulation of IFN- $\gamma$ production is multi-layered. The IFNG locus is only demethylated in effector and memory $\mathrm{T}$ cells [22], allowing for locus accessibility and transcription upon T cell activation. While the production of $\mathrm{T}$ cell effector molecules has been mainly attributed to changes in transcription and the presence of transcription factors [23]-[27], recently, the role of post-transcriptional regulation in $\mathrm{T}$ cells has also become appreciated [28]-[33]. Posttranscriptional regulation is mediated by sequence elements and structures present in both the 5' and 3' untranslated regions (UTRs) of mRNA molecules [34]-[37] and nucleoside modifications, such as adenine methylation [38]. By facilitating the binding of RNA binding proteins (RBPs), microRNAs and long non-coding RNAs, these regulators combined determine the actual protein output of a cell [37].

One of these sequence elements are adenylate uridylate-rich elements (AREs). AREs are AUUUA pentamers present in multimers in the 3'UTR of mRNA molecules [39],[40]. Interestingly, many cytokine transcripts contain AREs [37],[39]. They function as binding hubs for RBPs and microRNAs [39]-[41]. Binding to AREs by these factors mediate mRNA 
stability, localization and translation and thus fine-tunes the protein output [30],[41]-[44]. By deleting the 3'UTR AREs from cytokine mRNA, the protein production is decoupled from ARE-mediated post-transcriptional regulation [30],[43],[45]. We recently showed that AREs present in the Ifng 3'UTR dampen anti-tumoral responses in a murine melanoma model [46]. In fact, removal of AREs from the Ifng locus resulted in prolonged IFN- $\gamma$ production in a tumor suppressive microenvironment, which translated into substantially delayed tumor outgrowth and prolonged survival [46].

The 3'UTR of IFN- $\gamma$ is highly conserved between mice and men, in particular the region containing the AREs [30]. Therefore, we hypothesized that the regulation of IFN- $\gamma$ production is also conserved. To unravel the post-transcriptional regulation of IFN- $\gamma$ in primary human T cells, we removed a 160bp region by CRISPR-Cas9 technology from the IFNG 3'UTR locus that contained all AREs sequences. Similar to murine Ifng [46], removal of AREs from the human IFNG locus (ARE-Del) results in increased IFN- $\gamma$ production. Combining TCR gene transfer with ARE-deletion in primary human T cells confirmed increased IFN- $\gamma$ production by ARE-Del $\mathrm{T}$ cells in response to tumor cells. The ARE-mediated regulation of IFN- $\gamma$ is thus conserved in human T cells. 


\section{MATERIALS AND METHODS}

\section{Human PBMCs and cell culture}

Studies with human T cells from anonymized healthy donors were performed in accordance with the Declaration of Helsinki (Seventh Revision, 2013) after written informed consent (Sanquin). Peripheral blood mononuclear cells (PBMCs) were isolated through Lymphoprep density gradient separation (Stemcell Technologies). Cells were used after cryopreservation.

Human T cells were cultured in T-cell mixed media (Miltenyi) supplemented with 5\% heatinactivated human serum (Sanquin) and fetal bovine serum (FBS, Bodinco), 2mM L-glutamine, $20 \mathrm{IU} / \mathrm{mL}$ penicillin G sodium salts, $20 \mu \mathrm{g} / \mathrm{mL}$ streptomycin sulfate (all Sigma Aldrich), 100 IU/mL recombinant human (rh) IL-2 (Proleukin, Novartis) and 10 ng/mL rhIL-15 (Peprotech), and were cultured in a humidified incubator at $37^{\circ} \mathrm{C}+5 \% \mathrm{CO}_{2}$. Cells were cultured at a density between $0.5-1 * 10^{6}$ cells/mL. Medium was refreshed every 3 days.

\section{$T$ cell activation}

T cells were activated as previously described [47]. Briefly, 24-well plates were pre-coated overnight with $0.5 \mu \mathrm{g} / \mathrm{mL}$ rat $\alpha$-mouse IgG2a (clone MW1483, Sanquin) at $4{ }^{\circ} \mathrm{C}$. Plates were washed once with PBS, coated with $1 \mu \mathrm{g} / \mathrm{mL} \alpha-\mathrm{CD} 3$ (clone Hit3a, eBioscience) for a minimum of $2 \mathrm{~h}$ at $37^{\circ} \mathrm{C}$, and washed once with PBS. $1 * 10^{6}$ PBMCs/well were added in medium supplemented with $1 \mu \mathrm{g} / \mathrm{mL} \alpha-\mathrm{CD} 28$ (clone CD28.2, eBioscience). Cells were activated for $72 \mathrm{~h}$ in a humidified incubator at $37^{\circ} \mathrm{C}$ and $5 \% \mathrm{CO}_{2}$.

\section{crRNA and sequence primer design}

crRNAs and sequence primers were designed using the CRISPR and Primer design tools in Benchling (https://benchling.com, Table 1). Sequences were verified to be specific for the target of interest via BlastN and PrimerBlast (both NCBI).

\section{Genetic modification of human T cells with Cas9-RNPs}

Cas9 RNP production and T cell nucleofection was performed as previously described [48]. Briefly, Alt-R crRNA and ATTO550-labeled tracr-RNA were reconstituted to $100 \mu \mathrm{M}$ in Nuclease Free Duplex buffer (all Integrated DNA Technologies). As a negative control, nontargeting negative control crRNA \#1 was used (Integrated DNA Technologies). Oligos were mixed at equimolar ratios (i.e. $4.5 \mu \mathrm{L}$ total crRNA + 4.5 $\mu \mathrm{L}$ tracrRNA) in nuclease-free PCRtubes and denatured by heating at $95{ }^{\circ} \mathrm{C}$ for $5 \mathrm{~min}$ in a thermocycler. Nucleic acids were cooled down to room temperature prior to mixing them via pipetting with $30 \mu \mathrm{g}$ TrueCut Cas9 V2 
(Invitrogen) to produce Cas9 ribonuclear proteins (RNPs). Mixture was incubated at room temperature for at least $10 \mathrm{~min}$ prior to nucleofection.

For nucleofection, $1 * 10^{6} \mathrm{~T}$ cells/condition were harvested $72 \mathrm{~h}$ after $\alpha-\mathrm{CD} 3 / \alpha-\mathrm{CD} 28$ activation and transferred to DNA Lo-binding Eppendorf tubes (Eppendorf). Cells were washed once with PBS and supernatant was completely removed. Cells were resuspended in $20 \mu \mathrm{L}$ P2 Buffer (Lonza), Cas9 RNPs were added, and incubated for $2 \mathrm{~min}$. Cells were then electroporated in 16well strips in a 4D Nucleofector X unit (Lonza) with program EH-100. $100 \mu \mathrm{L}$ of pre-warmed complete medium was added and cells were allowed to recover for $5 \mathrm{~min}$ in a humidified incubator at $37{ }^{\circ} \mathrm{C}$ and $5 \% \mathrm{CO}_{2}$. Cells were transferred to 48 -well plates containing $500 \mu \mathrm{L}$ prewarmed complete medium and cultured in a humidified incubator at $37^{\circ} \mathrm{C}+5 \% \mathrm{CO}_{2}$.

CRISPR-mediated gene editing was tested on genomic DNA. Snapfrozen cell pellets $\left(1 * 10^{6}\right.$ cells) were incubated overnight at $56{ }^{\circ} \mathrm{C}$ while rotating at $850 \mathrm{RPM}$ in $50 \mu \mathrm{L}$ lysis buffer (50 $\mathrm{mM}$ Tris- $\mathrm{HCl}, 2.5 \mathrm{mM}$ EDTA, $50 \mathrm{mM} \mathrm{KCl}$ and $0.45 \%$ Tergitol at $\mathrm{pH} 8.0$ ) that was freshly supplemented with $1 \mu \mathrm{g} / \mathrm{mL}$ proteinase $\mathrm{K}$ (Roche). After deactivating proteinase $\mathrm{K}$ by incubating for $15 \mathrm{~min}$ at $95^{\circ} \mathrm{C}$, lysed cells were centrifuged for $10 \mathrm{~min}$ at $13.000 \mathrm{RPM}(20.000 \mathrm{~g})$. Supernatant was transferred to a new tube. The IFNG genomic locus was amplified by PCR (30s at $98^{\circ} \mathrm{C},\left(10 \mathrm{~s}\right.$ at $98^{\circ} \mathrm{C}, 30$ s at $65^{\circ} \mathrm{C}, 30$ s at $\left.72{ }^{\circ} \mathrm{C}\right) \mathrm{x} 40,7 \mathrm{~min}$ at $72^{\circ} \mathrm{C}, 2 \mathrm{~min}$ at $15^{\circ} \mathrm{C}$ ) with DreamTaq HotStart Green Polymerase (ThermoScientific) and primerpair IFNG_PCR_F and IFNG_PCR_R (Table 1) and subsequently analyzed on $0.8 \%$ agarose gel. For Sanger sequencing, PCR product was purified with NucleoSpin Gel and PCR Clean-up kit (Macherey Nagel) according to manufacturer's protocol (Baseclear).

ARE-deletion from IFNG mRNA was determined by total RNA extraction from snapfrozen pellets of $0.2^{*} 10^{6}$ cells activated for $3 \mathrm{~h}$ with $\alpha-\mathrm{CD} 3 / \alpha-\mathrm{CD} 28$ activated $\mathrm{T}$ cells using Trizol (Invitrogen). DNA contamination was removed with RNA Clean \& Concentrator 5 kit (Zymo Research) according to manufacturer's protocol. cDNA synthesis was performed in the presence or absence of SuperScript III Reverse Transcriptase according to manufacturer's protocol (Invitrogen). The resulting cDNA was amplified by PCR $\left(30 \mathrm{~s}\right.$ at $98{ }^{\circ} \mathrm{C},\left(10 \mathrm{~s}\right.$ at $98^{\circ} \mathrm{C}$, 30s at $62{ }^{\circ} \mathrm{C}, 30$ s at $72{ }^{\circ} \mathrm{C}$ ) $\mathrm{x} 40,7 \mathrm{~min}$ at $72{ }^{\circ} \mathrm{C}, 2 \mathrm{~min}$ at $15^{\circ} \mathrm{C}$ ) with with DreamTaq HotStart Green Polymerase and primerpair IFNG_3'PCR_F and IFNG_3'PCR_R (Table 1) and subsequently analyzed on a $2 \%$ agarose gel. 


\section{Generation of MART-1 TCR expressing T cells}

PBMCs were activated for $72 \mathrm{~h}$ with $\alpha-C D 3 / \alpha-C D 28$, harvested, and transduced with MART1 TCR retrovirus as previously described [49]. Briefly, non-tissue culture treated 24-well plates were coated with $50 \mu \mathrm{g} / \mathrm{mL}$ Retronectin (Takara) overnight at $4{ }^{\circ} \mathrm{C}$ and washed once with PBS. Subsequently, $300 \mu \mathrm{L}$ viral supernatant was added per well and was centrifuged for $1 \mathrm{~h}$ at $4{ }^{\circ} \mathrm{C}$ at $4000 \mathrm{rpm}(2820 \mathrm{~g}) .1 * 10^{6}$ freshly activated T cells were added per well, spun for $10 \mathrm{~min}$ at $1000 \mathrm{rpm}(180 \mathrm{~g})$, and cultured at $37{ }^{\circ} \mathrm{C}$ and $5 \% \mathrm{CO}_{2}$ in a humidified incubator. After $24 \mathrm{~h}$, cells were harvested and cultured in T25 flasks at a concentration of $0.8^{*} 10^{6}$ cells $/ \mathrm{mL}$ for 3 days in complete medium.

\section{Functional assays}

T cells were stimulated with $1 \mu \mathrm{g} / \mathrm{mL}$ pre-coated $\alpha$-CD3 and $1 \mu \mathrm{g} / \mathrm{mL}$ soluble $\alpha$-CD28 for indicated time points. MART-1 TCR-transduced T cells were co-cultured with HLA-A*0201+ MART $1^{\text {hi }}$ Mel $526\left(\right.$ MART1 $^{+}$), or HLA-A*0201 ${ }^{-}$MART1 $^{\text {lo }}$ Mel 888 (MART1 ${ }^{-}$) tumor cell lines [50]-[52], in a 1:1 effector to target (E:T) ratio for indicated time points. $1 \mu \mathrm{g} / \mathrm{mL}$ Brefeldin A (BD Biosciences) was added as indicated. Non-activated T cells were used as a negative control. All stimulations were performed in T cell mixed medium supplemented with $10 \%$ FBS, $2 \mathrm{mM}$ L-glutamine, 20U/mL penicillin G sodium salts and $20 \mu \mathrm{g} / \mathrm{mL}$ streptomycin sulfate.

\section{Flow cytometry and intracellular cytokine staining}

For flow cytometric analysis, cells were washed with FACS buffer (PBS, containing 1\% FBS and 2mM EDTA) and labeled with monoclonal antibodies $\alpha$-CD4 (clone SK3), $\alpha$-CD8 (clone SK1), $\alpha$-murine TCR beta (clone H57-597, all BD Biosciences), $\alpha$-IFN- $\gamma$ (clone 4S.B3), $\alpha$-IL2 (clone MQ1-17H12) and $\alpha$-TNF- $\alpha$ (clone MAb11) (all Biolegend). Near-IR (Life Technologies) was used to exclude dead cells from analysis. For intracellular cytokine staining, cells were cultured in the presence of $1 \mu \mathrm{g} / \mathrm{mL}$ Brefeldin A for indicated timepoints and were fixed and permeabilized with Cytofix/Cytoperm kit (BD Biosciences) according to manufacturer's protocol. Expression levels were acquired using FACSymphony (BD Biosciences) and data were analyzed using FlowJo (FlowJo LLC, version 10). For gating strategy, see Suppl Fig $1 A-B$.

\section{Real-time PCR analysis}

Total RNA was extracted using Trizol (Invitrogen). cDNA synthesis was performed with SuperScript III Reverse Transcriptase (Invitrogen), and real-time PCR was performed with 
SYBR green and a StepOne Plus RT-PCR system (both Applied Biosystems). Reactions were performed in duplicate or triplicate, and cycle threshold values were normalized to $18 S$ levels. Primer sequences for IFNG, TNF, and IL2 mRNA were previously described [47].

To determine the half-life of IFNG mRNA, T cells were activated for $3 \mathrm{~h}$ with indicated stimuli, and then treated with $5 \mu \mathrm{g} / \mathrm{ml}$ actinomycin D (ActD) (Sigma-Aldrich). Data were analyzed using StepOne Plus software (Applied Biosystems).

\section{Statistical analysis}

Results are expressed as mean \pm SD when indicated. Statistical analysis between groups was performed with Prism (GraphPad Software, version 8), using paired or ratio paired Student's ttest when comparing 2 groups, or two-way ANOVA with Bonferroni's correction for multiple comparisons when comparing more than 2 groups. P values $<0.05$ were considered to be statistically significant. 


\section{RESULTS}

\section{Deletion of AREs from the IFNG locus by CRISPR-Cas9}

The human IFNG 3'UTR contains 5 AU-rich elements (AREs), defined as AUUUA (Figure $\boldsymbol{1 A}$, underlined sequence). To remove all 5 ARE sequences within the 3'UTR of the IFNG locus, we designed 2 CRISPR guide RNAs (crRNAs) (Figure 1A, bold sequence). As a control, we included non-targeting crRNAs (control). PBMC-derived human primary $\mathrm{T}$ cells were activated with $\alpha$-CD3/ $\alpha-C D 28$ for 3 days prior to nucleofection with $30 \mu \mathrm{g}$ Cas9-RNP complexes (Figure 1B). Using ATTO-labeled tracrRNA allowed us to follow nucleofection efficiency by flow cytometry. 3 days after nucleofection, virtually all $\mathrm{CD}^{+}$and $\mathrm{CD} 4^{+} \mathrm{T}$ cells were positive for ATTO550 (control 97,8 0,9\%, ARE-Del 98,6 \pm 0,4 \%, Figure 1C,D). In line with the described cleavage pattern of S. pyogenes Cas9 [53], cleavage occurred between the $17^{\text {th }}$ and $18^{\text {th }}$ base of the designed crRNAs (Suppl Figure 2A). The 160 bp deletion containing the AREs was efficient, as revealed by both PCR and by Sanger sequencing of the genomic IFNG 3'UTR region (Figure 1E; Suppl Figure 2A). Importantly, nucleofection did not impact T cell survival (Figure 1D), and ARE-Del nucleofected T cells expanded as efficiently as control nucleofected T cells, with a $9.2 \pm 1.1$ fold vs $8.9 \pm 1.2$ fold expansion within 8 days after removal from $\alpha-C D 3 / \alpha-C D 28$.

To determine if gene editing affected the IFNG 3'UTR downstream of the ARE region, we extracted RNA from control and ARE-Del T cells. T cells were first activated for $3 \mathrm{~h}$ with $\alpha-$ $\mathrm{CD} 3 / \alpha-\mathrm{CD} 28$ to increase IFNG mRNA levels. After cDNA synthesis, we performed PCR from the IFNG mRNA coding region to the 3'end of the IFNG 3'UTR, resulting in a $509 \mathrm{bp}$ fragment for the WT and a 349 bp fragment for the ARE-Del IFNG mRNA (Suppl Figure 2B). The geneediting was thus specific for the ARE region and did not result in a premature transcriptional stop of the IFNG 3'UTR. In conclusion, ARE-deletion from the IFNG locus was efficient and specific in primary human $\mathrm{T}$ cells and did not impact $\mathrm{T}$ cell survival and expansion.

\section{ARE-deletion stabilizes IFNG mRNA and augments protein production in human $\mathrm{T}$ cells} We next studied whether ARE-deletion from the IFNG locus altered IFNG mRNA levels. In T cells that were rested for 9 days after nucleofection, IFNG mRNA levels were approximately 2-fold higher in ARE-Del T cells compared to control T cells (Figure 2A). In most donors, IFNG mRNA levels of ARE-Del T cells were also slightly increased upon $3 \mathrm{~h}$ stimulation with $\alpha-C D 3 / \alpha-C D 28$ compared to control T cells (Figure $2 A$ ). TNFA and IL2 mRNA levels remained unaltered, indicating IFNG mRNA specific alterations in ARE-Del T cells (Suppl 
Figure 3A). To determine IFNG mRNA half-life, T cells were treated with Actinomycin D, a drug that blocks de novo mRNA transcription. ARE-deletion significantly increased the stability of IFNG mRNA compared to control T cells (t1/2>2h compared to $\sim 70 \mathrm{~min}$, Figure $2 \boldsymbol{B})$. This is similar to murine ARE-Del T cells [46].

To determine whether ARE-deletion also modulated the IFN- $\gamma$ protein production and/or kinetics, we activated ARE-Del and control T cells with $\alpha-C D 3 / \alpha-C D 28$. To visualize the production kinetics, we added Brefeldin A for a maximum of the final $2 \mathrm{~h}$ of stimulation [54], and measured the production of IFN- $\gamma$ protein via intracellular cytokine staining. In nonactivated $\mathrm{T}$ cells, we did not observe any protein production by any $\mathrm{T}$ cell type (Figure $2 \mathrm{C}$ ), indicating that like control $\mathrm{T}$ cells, ARE-Del $\mathrm{T}$ cells require $\mathrm{T}$ cell activation for cytokine production. Irrespective of the ARE-deletion, the production of IFN- $\gamma$ by $\mathrm{T}$ cells peaks at $6 \mathrm{~h}$ after stimulation (Figure 2C), as previously described [3],[47]. However, already from $2 \mathrm{~h}$ of activation onwards, we found increased percentages of IFN- $\gamma$-producing T cells in ARE-Del $\mathrm{CD}^{+} \mathrm{T}$ cells compared to control T cells $($ Figure $2 \boldsymbol{C}, \boldsymbol{D})$. This increase in cytokine production was specific to IFN- $\gamma$ and was not observed for TNF- $\alpha$ or IL-2 (Suppl Figure 3B, C). Even though we did not find overt differences in the IFN- $\gamma$ production per cell (Figure $2 D$, bottom row), deletion of AREs promoted the IFN- $\gamma$ production in both $\mathrm{CD}^{+}$and in $\mathrm{CD}^{+} \mathrm{T}$ cells (Figure 2D, top row). Thus, ARE-deletion in the IFNG 3'UTR increases the stability of IFNG mRNA and augments the production of IFN- $\gamma$ protein.

\section{Prolonged cytokine production by human ARE-Del T cells upon removal of stimuli}

We next questioned if ARE-deletion also modulates mRNA expression and protein production kinetics upon removal of stimulation. We therefore restimulated ARE-Del T cells and control T cells with $\alpha-C D 3 / \alpha-C D 28$ for $72 \mathrm{~h}$, and transferred the cells to new wells to remove the stimulus. $24 \mathrm{~h}$ after removal of the stimulus, WT T cells expressed slightly lower IFNG mRNA levels than ARE-Del T cells, which further dropped after 48h (Figure 3A). In contrast, AREDel T cells maintained equally high IFNG mRNA levels for up to 72h (Figure 3A).

Intriguingly, also the IFN- $\gamma$ protein production was altered by ARE-deletion. Even though TNF$\alpha$ and IL-2 production was lost at 24h after removal from stimulation (Suppl Figure 3D), AREDel CD ${ }^{+} \mathrm{T}$ cells retained their capacity to produce IFN- $\gamma$ for up to $72 \mathrm{~h}$ (Figure $3 B$, $C$ ). This also translated in higher IFN- $\gamma$ production per cell at $24 \mathrm{~h}$ post antigen removal, as determined by the geoMFI of the IFN- $\gamma$ producing T cells (Figure $3 C$ ). This increased production is also 
observed in CD4 ${ }^{+}$ARE-Del T cells, albeit only for the first 24h (Figure 3C). Together, these data show that, similar to murine T cells [30], deletion of AREs from the IFNG 3' UTR results in prolonged IFN- $\gamma$ production in human T cells.

\section{TCR-engineered ARE-Del T cells are superior IFN- $\gamma$ producers in response to tumor cells}

IFN- $\gamma$ mediated signaling is key for effective anti-tumoral $\mathrm{T}$ cell responses [55]. This prompted us to study whether ARE-Del $\mathrm{T}$ cells are also superior IFN- $\gamma$ producers when encountering tumor cells. To this end, we combined ARE-deletion with TCR gene transfer. We first retrovirally transduced human $\mathrm{CD}^{+} \mathrm{T}$ cells with a codon-optimized MART-1 TCR that recognizes the HLA-A*0201 restricted epitope of MART-1 (aa26-35) [49]. After 5 days, MART-1 TCR engineered T cells were restimulated with $\alpha-C D 3 / \alpha-C D 28$ for $72 \mathrm{~h}$ prior to nucleofection. Of note, ARE-deletion was also highly efficient in TCR-engineered T cells (Suppl Figure 3E). Furthermore, the combined TCR engineering with subsequent nucleofection did not affect the viability or the expansion capacity of ARE-Del versus control MART-1 TCR engineered T cells $(92.3 \pm 2.3$ vs $91.3 \pm 2.6 \%$ live cells, and $12.9 \pm 5.2$ vs $13.2 \pm 4.2$ fold expansion within 7 days, respectively).

To study the production of IFN- $\gamma$ in response to tumor cells, we exposed MART-1 TCRengineered ARE-Del T cells or control T cells to a MART- ${ }^{\text {hi }}$ HLA-A*0201+ melanoma cell line $\left(\mathrm{MART}^{-}{ }^{+}\right.$) and to a MART- $1^{\text {lo }} \mathrm{HLA}-\mathrm{A}^{*} 0201^{-}$melanoma cell line (MART-1 ${ }^{-}$) [50]-[52]. As expected, MART-1 TCR-engineered T cells only produce cytokines when co-cultured with MART- $1^{+}$tumor cells (Figure $4 A$ ). Interestingly, after 6 h of co-culture with MART- $1^{+}$cells, a significantly higher percentage of MART-1 TCR-engineered ARE-Del CD8 ${ }^{+} \mathrm{T}$ cells produced IFN- $\gamma$ than the control MART-1 TCR-engineered T cells (Figure 4A, B). Again, the higher percentage of IFN- $\gamma$ producing cells did not translate into significantly increased cytokine production per cell, as determined by the GeoMFI of the IFN- $\gamma^{+}$T cells (Figure $4 B$ ).

The increased percentage of IFN- $\gamma$ producing cells in ARE-Del MART-1 TCR-engineered T cells compared to control T cells was also observed after $24 \mathrm{~h}$ of co-culture (Figure $4 B$ ). T cells were retransferred to freshly seeded tumor cells for another $24 \mathrm{~h}$ and cytokine production was measured. At this time point, i.e. $48 \mathrm{~h}$ of co-culture, no differences in cytokine production were observed (Figure 4B). Overall, these finding show that the generation of antigen-specific AREDel T cells is feasible and allows to drive enhanced and prolonged IFN- $\gamma$ production in response to target cells. 


\section{DISCUSSION}

Here we show that the deletion of AREs from the IFNG 3'UTR in primary human T cells results in higher IFNG mRNA levels, enhanced numbers of IFN- $\gamma$ producing $\mathrm{T}$ cells and prolonged IFN- $\gamma$ production. These findings are in line with previous findings with murine ARE-Del T cells [43],[46]. Thus, the highly conserved ARE region in the IFNG 3'UTR locus also provides conserved post-transcriptional regulation in T cells.

We also observed differences between murine and human ARE-Del T cells, which are primarily of quantitative nature. Murine ARE-Del T cells produce more IFN- $\gamma$ per cell than wildtype T cells [46]. We did not observe this difference in human T cells. The overall mRNA stability in activated human control $\mathrm{T}$ cells is also lower than that of murine $\mathrm{T}$ cells. Whereas murine $\mathrm{T}$ cells show a t1/2 > $\mathrm{h}$ upon antigen stimulation [30],[33], human control T cells activated with $\alpha-C D 3 / \alpha-C D 28$ only reach a t1/2 $\sim 70 \mathrm{~min}$. This also translates into lower overall IFN- $\gamma$ protein output in human $\mathrm{T}$ cells, both in terms of responding $\mathrm{T}$ cells $(60-80 \%$ in murine wild type $\mathrm{T}$ cells versus 30-50\% in human T cells upon PMA-Ionomycin stimulation [47],[54]), and in terms of production kinetics. In fact, even though human and murine T cells initiate the IFN- $\gamma$ production in the same time frame, human $\mathrm{T}$ cells cease to produce IFN- $\gamma$ faster. To date, it remains unresolved whether these differences stem from different activation methods in murine and human T cells (MEF cells expressing antigen and B7.1 in murine [46] versus $\alpha-C D 3 / \alpha-$ CD28 in human T cells), from different $\mathrm{T}$ cell responsiveness due to different requirements on nutrients and stimuli during culture conditions, from higher diversity in human $\mathrm{CD}^{+} \mathrm{T}$ cell populations [56], or from intrinsic differences between murine and human T cells. Irrespective of the observed quantitative differences, we show here that ARE sequences are essential for the regulation of IFNG mRNA stability and IFN- $\gamma$ protein output in both murine [46] and human T cells.

Excessive production of IFN- $\gamma$ can induce immunopathology [57]-[65]. However, the AREs solely fine-tune post-transcriptional regulation of IFN- $\gamma$ production, while leaving the requirement of antigen recognition and transcriptional regulation in murine and human $\mathrm{T}$ cells intact ([46], this study). Indeed, in studies with long term memory ARE-Del T cells in a Listeria infection and in a B16 melanoma model, we find the increased and prolonged IFN- $\gamma$ production also only in the presence of tumor cells or after antigenic challenge [46]. We therefore anticipate only limited side effects of the ARE-deletion in T cells. 
We here combined retroviral TCR engineering with efficient CRISPR-Cas9 mediated genome editing. This experimental setup is a powerful tool to study gene modification in human T cells in an antigen-specific setting. Furthermore, TCR engineering with CRISPR-Cas9 technology could also be useful for therapeutic purposes. It is noteworthy that upon CRISPR-Cas9 mediated genome editing, TCR-engineered $\mathrm{T}$ cells maintained their capacity to expand, a feature that is critical for generating large numbers of $\mathrm{T}$ cells required for cellular products.

In conclusion, the generation of primary human ARE-Del $\mathrm{T}$ cells revealed that fundamental post-transcriptional mechanisms of IFNG regulation are conserved throughout evolution. 


\section{AUTHOR CONTRIBUTIONS / ACKNOWLEDGEMENTS}

JJFH, BP, and MCW designed experiments, JJFH, BP and AG performed experiments, JJFH, $\mathrm{BP}$ and MCW analyzed data, and JJFH and MCW wrote the manuscript. MCW supervised the project.

The authors would like to thank Dr. Ton Schumacher (Netherlands Cancer Institute) for providing MART-1 TCR viral supernatants, Nordin Zandhuis for technical assistance, and the Wolkers' lab for scientific input and critical reading of the manuscript.

This research was supported by KWF Kankerbestrijding (10132), the Dutch Science Foundation (VIDI grant 917.14.214), and Oncode Institute, all to M.C.W.

\section{CONFLICT OF INTEREST}

The authors have no conflict of interest to disclose. 


\section{REFERENCES}

1. Almeida JR, Price DA, Papagno L, Sauce D, Bornstein E, Asher TE, Samri A, et al. Superior control of HIV-1 replication by CD8+ T cells is reflected by their avidity, polyfunctionality, and clonal turnover. J. Exp. Med. 2007; 204:2473-2485.DOI: 10.1084/jem.20070784.

2. Ciuffreda D, Comte D, Cavassini M, Giostra E, Bu L, Perruchoud M, Heim MH, et al. Polyfunctional HCV-specific T-cell responses are associated with effective control of HCV replication. Eur. J. Immunol. 2008; 38:2665-2677.DOI: 10.1002/eji.200838336.

3. Han Q, Bagheri N, Bradshaw EM, Hafler DA, Lauffenburger DA, Love JC. Polyfunctional responses by human T cells result from sequential release of cytokines. Proc. Natl. Acad. Sci. 2012; 109:1607-1612.DOI: 10.1073/pnas.1117194109.

4. Beatty GL, Paterson Y. IFN- $\gamma$-Dependent Inhibition of Tumor Angiogenesis by TumorInfiltrating CD4+ T Cells Requires Tumor Responsiveness to IFN- $\gamma$. J. Immunol. 2001; 166:2276-2282.DOI: 10.4049/jimmunol.166.4.2276.

5. Schroder K, Hertzog PJ, Ravasi T, Hume DA. Interferon-gamma: an overview of signals, mechanisms and functions. J. Leukoc. Biol. 2004; 75:163-89.DOI: 10.1189/jlb.0603252.

6. Libregts SF, Gutie L, Bruin AM De, Wensveen FM, Papadopoulos P, Ijcken W Van, Zeliha $\mathbf{O}$, et al. Chronic IFN- $\gamma$ production in mice induces anemia by reducing erythrocyte life span and inhibiting erythropoiesis through an IRF-1/PU.1 axis. Blood. 2011; 118:25782589.DOI: 10.1182/blood-2010-10-315218.

7. De Bruin AM, Voermans C, Nolte MA. Impact of interferon- $\gamma$ on hematopoiesis. Blood. 2014; 124:2479-2486.DOI: 10.1182/blood-2014-04-568451.

8. Lin F ching, Young HA. Interferons: Success in anti-viral immunotherapy. Cytokine Growth Factor Rev. 2014; 25:369-376.DOI: 10.1016/j.cytogfr.2014.07.015.

9. Soudja S, Chandrabos C, Yakob E, Veenstra M, Palliser D, Lauvau G. Memory-T-CellDerived Interferon-g Instructs Potent Innate Cell Activation for Protective Immunity. Immunity. 2014; 40:974-968.DOI: 10.1016/j.immuni.2014.05.005.

10. Selders GS, Fetz AE, Radic MZ, Bowlin GL. An overview of the role of neutrophils in innate immunity, inflammation and host-biomaterial integration. Regen. Biomater. 2017:5568.DOI: $10.1093 / \mathrm{rb} / \mathrm{rbw} 041$. 
11. Nathan C, Murray H, Wiebe M, Rubin B. Identification of interferon-gamma as the lymphokine that activates human macrophage oxidative metabolism and antimicrobial activity. J. Exp. Med. 1983; 158:670-689.DOI: 10.1084/jem.158.3.670.

12. Martinez FO, Helming L, Gordon S. Alternative Activation of Macrophages: An Immunologic Functional Perspective. Annu. Rev. Immunol. 2009; 27:451-483.DOI: 10.1146/annurev.immunol.021908.132532.

13. Li C, Xu MM, Wang K, Adler AJ, Vella AT, Zhou B. Macrophage polarization and Metainflammation. Transl. Res. 2018; 191:29-44.DOI: 10.1016/j.trsl.2017.10.004.

14. Newport M, Huxley C, Huston S, Hawrylowicz C, Oostra B, Williamson R, Levin M. A Mutation in the Interferon-g-Receptor Gene and Susceptibility to Mycobacterial Infection. N. Engl. J. Med. 1996; 355:1941-1949.DOI: 10.1056/NEJM199612263352602.

15. Dorman SE, Holland SM. Mutation in the signal-transducing chain of the interferon- $\gamma$ receptor and susceptibility to mycobacterial infection. J. Clin. Invest. 1998; 101:23642369.DOI: 10.1172/JCI2901.

16. Zhang S, Chapgier A, Yang K, Bustamante J, Puel A, Picard C, Abel L, et al. Inborn errors of interferon (IFN)-mediated immunity in humans insights into the respective roles of IFN-a/b, IFN-g and IFN-d in host defense. Immunol. Rev. 2008; 276:29-40.DOI: 10.1111/j.1600-065X.2008.00698.x.

17. Kaplan DH, Shankaran V, Dighe AS, Stockert E, Aguet M, Old LJ, Schreiber RD. Demonstration of an interferon-gamma dependent tumor surveillance system in immunocompetent mice. Proc. Natl. Acad. Sci. 1998; 95:7556-7561.DOI: 10.1073/pnas.95.13.7556.

18. Shankaran V, Ikeda H, Bruce AT, White JM, Swanson PE, Old LJ, Schreiber RD. IFN-g and lymphocytes prevent primary tumour development and shape tumour immunogenicity. Nature. 2001; 410:1107-1111.DOI: 10.1038/35074122.

19. Patel SJ, Sanjana NE, Kishton RJ, Eidizadeh A, Vodnala SK, Cam M, Gartner JJ, et al. Identification of essential genes for cancer immunotherapy. Nature. 2017; 548:537542.DOI: 10.1038/nature23477.

20. Ayers M, Lunceford J, Nebozhyn M, Murphy E, Loboda A, Kaufman DR, Albright A, et al. IFN- $\gamma$-related mRNA profile predicts clinical response to PD-1 blockade. J. Clin. 
Invest. 2017; 127:2930-2940.DOI: 10.1172/JCI91190.

21. Gao J, Shi LZ, Zhao H, Chen J, Xiong L, He Q, Chen T, et al. Loss of IFN- $\gamma$ pathway genes in tumor cells as a mechanism of resistance to anti-CTLA-4 therapy. Cell. 2016; 167:397404.DOI: 10.1016/j.physbeh.2017.03.040.

22. Jones B, Chen J. Inhibition of IFN-gamma transcription by site-specific methylation during T helper cell development. EMBO J. 2006; 25:2443-52.DOI: 10.1038/sj.emboj.7601148.

23. Sica A, Dorman L, Viggiano V, Cippitelli M, Ghosh P, Rice N, Young HA. Interaction of NF-kB and NFAT with the Interferon-g Promoter. J. Biol. Chem. 1997; 272:3041230420.DOI: $10.1074 / j b c .272 .48 .30412$.

24. Intlekofer AM, Takemoto N, Wherry EJ, Longworth SA, Northrup JT, Palanivel VR, Mullen AC, et al. Effector and memory CD8+ T cell fate coupled by T-bet and eomesodermin. Nat. Immunol. 2005; 6:1236-1244.DOI: 10.1038/ni1268.

25. Koch A, Raidl M, Lux M, Mu K. IL-12-induced T-bet expression and IFN-g release in lymphocytes from asthmatics - Role of MAPkinases ERK-1/-2, p38 MAPK and effect of dexamethasone. Respitory Med. 2007; 101:1321-1330.DOI: 10.1016/j.rmed.2006.10.010.

26. Gray SM, Kaech SM, Staron MM. The interface between transcriptional and epigenetic control of effector and memory. Immunol. Rev. 2014; 261:157-168.DOI: 10.1111/imr.12205.

27. Conley JM, Gallagher MP, Berg LJ. T cells and gene regulation: The switching on and turning up of genes after T cell receptor stimulation in CD8 T cells. Front. Immunol. 2016; 7.DOI: 10.3389/fimmu.2016.00076.

28. Ganguly K, Giddaluru J, August A, Khan N. Post-transcriptional Regulation of Immunological Responses through Riboclustering. Front. Immunol. 2016; 7.DOI: 10.3389/fimmu.2016.00161.

29. Hoefig KP, Heissmeyer V. Posttranscriptional regulation of T helper cell fate decisions. $J$. Cell Biol. 2018; 217:2615-2631.DOI: 10.1083/jcb.201708075.

30. Salerno F, Engels S, van den Biggelaar M, Alphen FPJ Van, Guislain A, Zhao W, Hodge DL, et al. Translational repression of pre-formed cytokine-encoding mRNA prevents chronic activation of memory T cells. Nat. Immunol. 2018; 19:828-837.DOI: 10.1038/s41590018-0155-6. 
31. Turner M, Díaz-Muñoz MD. RNA-binding proteins control gene expression and cell fate in the immune system. Nat. Immunol. 2018; 19:120-129. Available at: http://dx.doi.org/10.1038/s41590-017-0028-4.DOI: 10.1038/s41590-017-0028-4.

32. Gagnon JD, Kageyama R, Shehata HM, Fassett MS, Mar DJ, Wigton EJ, Johansson K, et al. miR-15/16 Restrain Memory T Cell Differentiation, Cell Cycle, and Survival. CellReports. 2019; 28:2169-2181.DOI: 10.1016/j.celrep.2019.07.064.

33. Salerno F, Freen-van Heeren JJ, Guislain A, Nicolet BP, Wolkers MC. Costimulation through TLR2 Drives Polyfunctional CD8+ T Cell Responses. J. Immunol. 2019; 202:714723.DOI: $10.4049 /$ jimmunol.1801026.

\section{Cohen-Chalamish S, Hasson A, Weinberg D, Namer LS, Banai Y, Osman F, Kaempfer}

R. Dynamic refolding of IFN-gamma mRNA enables it to function as PKR activator and translation template. Nat. Chem. Biol. 2009; 5:896-903.DOI: 10.1038/nchembio.234.

35. Kafasla P, Skliris A, Kontoyiannis DL. Post-transcriptional coordination of immunological responses by RNA-binding proteins. Nat. Immunol. 2014; 15:492-502.DOI: 10.1038/ni.2884.

36. Turner M, Galloway A, Vigorito E. Noncoding RNA and its associated proteins as regulatory elements of the immune system. Nat. Immunol. 2014; 15:484-491.DOI: 10.1038/ni.2887.

37. Salerno F, Wolkers MC. T-cells require post-transcriptional regulation for accurate immune responses. Biochem. Soc. Trans. 2015:1201-1207.DOI: 10.1042/BST20150154.

38. Yue Y, Liu J, He C. RNA N6-methyladenosine methylation in post-transcriptional gene expression regulation. Genes Dev. 2015; 29:1343-1355.DOI: 10.1101/gad.262766.115.

39. Barreau C, Paillard L, Osborne HB. AU-rich elements and associated factors: are there unifying principles? Nucleic Acids Res. 2005; 33:7138-50.DOI: 10.1093/nar/gki1012.

40. Beisang D, Bohjanen P. Perspectives on the ARE as it turns 25 years old. Wiley Interdiscip Rev RNA. 212AD; 3:719-731.DOI: 10.1002/wrna.1125.

41. Jing Q, Huang S, Guth S, Zarubin T, Motoyama A, Chen J, Di Padova F, et al. Involvement of MicroRNA in AU-Rich Element-Mediated mRNA Instability. Cell. 2005; 120:623-634.DOI: 10.1016/j.cell.2004.12.038. 
42. Stoecklin G, Lu M, Rattenbacher B, Moroni C. A constitutive decay element promotes tumor necrosis factor alpha mRNA degradation via an AU-rich element-independent pathway. Mol. Cell. Biol. 2003; 23:3506-15.DOI: 10.1128/MCB.23.10.3506-3515.2003.

43. Hodge DL, Berthet C, Coppola V, Kastenmüller W, Buschman MD, Schaughency PM, Shirota H, et al. IFN-gamma AU-rich element removal promotes chronic IFN-gamma expression and autoimmunity in mice. J. Autoimmun. 2014; 53:33-45.DOI: 10.1016/j.jaut.2014.02.003.

44. Vlasova-St. Louis I, Bohjanen PR. Post-Transcriptional Regulation of Cytokine Signaling by AU-Rich and GU-Rich Elements. J. Interf. Cytokine Res. 2014; 34:233-241.DOI: 10.1089/jir.2013.0108.

45. Kontoyiannis D, Pasparakis M, Pizarro TT, Cominelli F, Kollias G. Impaired On/Off Regulation of TNF Biosynthesis in Mice Lacking TNF AU-Rich Elements: Implications for Joint and Gut-Associated Immunopathologies. Immunity. 1999; 10:387-398.DOI: 10.1016/S1074-7613(00)80038-2.

46. Salerno F, Guislain A, Freen-van Heeren JJ, Benoit P, Young HA, Wolkers MC. Critical role of post-transcriptional regulation for IFN- $\gamma$ in tumor-infiltrating $\mathrm{T}$ cells. Oncoimmunology. 2018; 8.DOI: 10.1080/2162402X.2018.1532762.

47. Nicolet BP, Guislain A, Wolkers MC. Combined Single-Cell Measurement of Cytokine mRNA and Protein Identifies T Cells with Persistent Effector Function. J. Immunol. 2017; 198:962-970.DOI: 10.4049/jimmunol.1601531.

48. Seki A, Rutz S. Optimized RNP transfection for highly efficient CRISPR/Cas9-mediated gene knockout in primary $\mathrm{T}$ cells. J. Exp. Med. 2018:jem.20171626.DOI: 10.1084/jem.20171626.

49. Gomez-Eerland R, Nuijen B, Heemskerk B, van Rooij N, van den Berg JH, Beijnen JH, Uckert W, et al. Manufacture of Gene-Modified Human T-Cells with a Memory Stem/Central Memory Phenotype. Hum. Gene Ther. Methods. 2014; 25:277-287.DOI: 10.1089/hgtb.2014.004.

50. Topalian SL, Solomon D, Rosenberg SA. Tumor-specific cytolysis by lymphocytes infiltrating human melanomas. J. Immunol. 1989; 142:3714-3725.

51. Marincola FM, Shamamian P, Simonis TB, Abati A, Dea TO, Fetsch P, Yannelli J, et 
al. Locus-Specific Analysis of Human Leukocyte Antigen Class I Expression in Melanoma Cell Lines. J. Immunother. with Emphas. Tumor Immunol. 1994; 16:13-23.

52. Cormier JN, Panelli MC, Hackett JA, Bettinotti MP, Wunderlich J, Parker LL, Restifo NP, et al. Natural variation of the expression of HLA and endogenous antigen modulates CTL recognition in an in vitro melanoma model. Int. J. Cancer. 1999; 80:781-790.

53. Jinek M, Chylinski K, Fonfara I, Hauer M, Doudna JA, Charpentier E. A Programmable Dual-RNA-Guided DNA Endonuclease in Adaptive Bacterial Immunity. Science (80-. ). 2012; 337:816-821.DOI: 10.1126/science.1225829.

54. Salerno F, Paolini NA, Stark R, von Lindern M, Wolkers MC. Distinct PKC-mediated posttranscriptional events set cytokine production kinetics in CD8+ T cells. Proc. Natl. Acad. Sci. 2017; 114:9677-9682.DOI: 10.1073/pnas.1704227114.

55. Alspach E, Lussier DM, Schreiber RD. Interferon $\gamma$ and Its Important Roles in Promoting Cancer Immunity. Cold Spring Harb. Perspect. Biol. 2019; 11.DOI: 10.1101/cshperspect.a028480.

56. Nicolet BP, Guislain A, van Alphen FPJ, Gomez-Eerland R, Schumacher TN, van den Biggelaar M, Wolkers M. CD29 marks superior cytotoxic human CD8+ T cells. bioRxiv. 2019.DOI: $10.1101 / 562512$.

57. Ito R, Shin-Ya M, Kishida T, Urano A, Takada R, Sakagami J, Imanishi J, et al. Interferon- $\gamma$ is causatively involved in experimental inflammatory bowel disease in mice. Clin. Exp. Immunol. 2006; 146:330-338.DOI: 10.1111/j.1365-2249.2006.03214.x.

58. Rafa H, Amri M, Saoula H, Belkhelfa M, Medjeber O, Boutaleb A. Involvement of Interferon- $\gamma$ in Bowel Disease Pathogenesis by Nitric Oxide Pathway: A Study in Algerian Patients. J. Interf. Cytokine Res. 2010; 30:691-697.DOI: 10.1089/jir.2010.0012.

59. Arellano G, Ottum PA, Reyes LI, Burgos PI. Stage-specific role of interferon- $\gamma$ in experimental autoimmune encephalomyelitis and multiple sclerosis. Front. Immunol. 2015; 6.DOI: $10.3389 /$ fimmu.2015.00492.

60. Ostler T, Davidson W, Ehl S. Virus clearance and immunopathology by CD8+ T cells during infection with respiratory syncytial virus are mediated by IFN- $\gamma$. Eur. J. Immunol. 2002; 32:2117-2123.DOI: 10.1002/1521-4141(200208)32:8<2117::AID-IMMU2117>3.0.CO;2-C.

61. Badovinac VP, Hamilton SE, Harty JT. Viral infection results in massive CD8+ T cell 
expansion and mortality in vaccinated perforin-deficient mice. Immunity. 2003; 18:463474.DOI: 10.1016/S1074-7613(03)00079-7.

62. Kuphal S, Bosserhoff A. Interferon-gamma-dependent mechanisms of mycobacteriainduced pulmonary immunopathology: the role of angiostasis and CXCR3-targeted chemokines for granuloma necrosis. J. Pathol. 2007; 212:295-305.DOI: 10.1002/path.

\section{Beccaria CG, Vesely MCA, Vernengo FF, Gehrau RC, Ramello MC, Boari JT, Serrán} MG, et al. Galectin-3 deficiency drives lupus-like disease by promoting spontaneous germinal centers formation via IFN- $\gamma$. Nat. Commun. 2018; 9.DOI: 10.1038/s41467-018-04063-5.

64. Ivashkiv LB. IFN $\gamma$ : signalling, epigenetics and roles in immunity, metabolism, disease and cancer immunotherapy. Nat. Rev. Immunol. 2018; 18:545-558.DOI: 10.1016/j.physbeh.2017.03.040.

65. Lounder DT, Bin Q, de Min C, Jordan MB. Treatment of refractory hemophagocytic lymphohistiocytosis with emapalumab despite severe concurrent infections. Blood Adv. 2019; 3:47-50.DOI: 10.1182/bloodadvances.2018025858. 


\section{FIGURE LEGENDS}

\section{Figure 1 - Generation of primary human ARE-Del T cells}

(A) Sequence of the human IFNG 3' UTR. Translation stop site is indicated with an asterisk, crRNA sequences are bold capitals, AREs are underlined capitals. (B) Graphical representation of the experimental setup. (C and D) PBMCs were stimulated for $72 \mathrm{~h}$ with $\alpha-C D 3 / \alpha-C D 28$ and subsequently nucleofected with Cas9 RNPs with ATTO550 labeled crRNAs targeting the 3'UTR of IFNG (ARE-Del), or with non-targeting control crRNA (Control). (C) Representative histograms of Cas9 RNP-ATTO 550 fluorescence gated on live CD8 ${ }^{+}$T cells (black) and live $\mathrm{CD}^{+} \mathrm{T}$ cells (gray). Dotted histograms represent non-nucleofected T cells. (D) Compiled data on ATTO550 fluorescence (left) and percentage of live cells (right) from $\mathrm{n}=5$ healthy donors from 3 independent experiments gated on $\mathrm{CD}^{+}$and $\mathrm{CD}^{+} \mathrm{T}$ cells, respectively. (E) AREdeletion was analyzed by genomic PCR and subsequent gel analysis.

Figure 2 - Enhanced IFNG mRNA levels, mRNA stability and protein output in ARE-Del T cells

(A-B) $\mathrm{T}$ cells rested 9 days and were left untreated or restimulated for $3 \mathrm{~h}$ with $\alpha-C D 3 / \alpha-C D 28$. (A) IFNG mRNA levels as determined by RT-PCR from $\mathrm{n}=6$ donors from 2 independent experiments (paired Student's t-test; * $\mathrm{p}<0.05$, ns, not significant). (B) T cells were activated for $3 \mathrm{~h}$ with $\alpha-\mathrm{CD} 3 / \alpha-\mathrm{CD} 28$. Actinomycin $\mathrm{D}$ was added to block de novo mRNA transcription, and IFNG mRNA stability was determined following 0, 60 and 120 minutes of Actinomycin D treatment. $\mathrm{n}=4$ donors from 2 independent experiments (Two-way ANOVA; ${ }^{*} \mathrm{p}<0.05, * * \mathrm{p}<$ 0.01). (C and D) Resting T cells were restimulated with $\alpha-C D 3 / \alpha-C D 28$ in the presence of Brefeldin A for indicated time points. (C) Representative dot plots of IFN- $\gamma$ production gated on live $\mathrm{CD}^{+} \mathrm{T}$ cells. (D) Compiled data on IFN- $\gamma^{+}$cells (top row) and IFN- $\gamma$ geoMFI (bottom row) gated on IFN- $\gamma^{+} \mathrm{CD}^{+}$and $\mathrm{CD}^{+} \mathrm{T}$ cells from $\mathrm{n}=6-13$ donors from 5-7 independent experiments after 2, 4 and $6 \mathrm{~h}$ of stimulation (paired Student's t-test; ${ }^{*} \mathrm{p}<0.05$, ${ }^{*} \mathrm{p}<0.01$, ns, not significant). Brefeldin A was added during the last $2 \mathrm{~h}$ of activation. $\mathrm{T}$ cells cultured in the absence of stimuli were used as negative control.

\section{Figure 3 - Prolonged IFN- $\gamma$ production in ARE-Del T cells in the absence of stimulation}

Rested T cells (11 days) were restimulated for $72 \mathrm{~h}$ with $\alpha-C D 3 / \alpha-C D 28$ and removed from stimulus for indicated time. (A) IFNG mRNA levels as determined by RT-PCR from $\mathrm{n}=4$ donors from 1 experiment (paired Student's t-test; ${ }^{*} \mathrm{p}<0.05$, ns, not significant). (B and $\mathbf{C}$ ) 
IFN- $\gamma$ protein production was assessed by adding Brefeldin A $4 \mathrm{~h}$ prior to IFN- $\gamma$ production assessment. (B) Representative concatenated dot plots of IFN- $\gamma$ production gated on live $\mathrm{CD}^{+}$ T cells after removal from stimulus for indicated time points. (C) Compiled data on IFN- $\gamma$ protein production from $\mathrm{n}=7$ donors from 3 independent experiments (Ratio paired Student's $\mathrm{t}$-test; $* \mathrm{p}<0.05, * * \mathrm{p}<0.01, \mathrm{~ns}$, not significant).

\section{Figure 4 - Enhanced IFN- $\gamma$ production by ARE-Del T cells upon target cell recognition}

MART-1 TCR-engineered T cells were cocultured with MART-1 ${ }^{+}$and MART-1 ${ }^{-}$cell lines expressing MART-1 peptide for indicated timepoints. Brefeldin A was added $2 \mathrm{~h}$ prior to IFN$\gamma$ production assessment. (A) Representative concatenated dot plots of IFN- $\gamma$ production gated on live $\mathrm{CD}^{+}$MART-1 TCR ${ }^{+} \mathrm{T}$ cells after 6, 24 and 48h of co-culture. (B) Compiled data from $\mathrm{n}=4$ donors from 3 independent experiments (paired Student's t-test; ${ }^{*} \mathrm{p}<0.05$, ns, not significant).

\section{Supplemental Figure 1 - Gating strategies to determine nucleofection and transduction efficiency and $T$ cell cytokine production}

Gating strategy for the flow cytometric analysis of human $\mathrm{CD}^{+} \mathrm{T}$ cells after nucleofection and antibody-mediated stimulation (A), or after retroviral transduction and coculture with MART$1^{+}$and MART-1 ${ }^{-}$target cells (B). In both examples, cells were stained with $\alpha-C D 4, \alpha-C D 8$, Near-IR live/dead dye, $\alpha$-IFN- $\gamma$, and in the case of (B) with $\alpha$-murine TCR beta. Data were collected with FACSSymphony flow cytometer and analyzed with FlowJo software. Human T cells are identified by their scatter properties (FSC-A x SSC-A plot), and doublets were excluded by gating on FSC-H x FSC-W and SSC-H x SSC-W. Dead cells are excluded based on Near-IR live/dead dye. CD8 ${ }^{+} \mathrm{T}$ cells are identified by $\alpha$-CD8 staining. Nucleofected cells are determined based on ATTO550 tracrRNA staining. MART-1 TCR-transduced T cells are determined by $\alpha$-murine TCR beta staining. In all cases, negative controls or non-stimulated cells were used to set the gates. IFN- $\gamma$ production is determined by $\alpha-$ IFN- $\gamma$ staining. TNF- $\alpha$ and IL-2 production are determined in a similar fashion.

\section{Supplemental Figure 2 - Genomic deletion of the IFNG 3' UTR AREs does not impact 3' UTR addition}

(A) Sanger sequencing of control and ARE-Del T cells. crRNA guides are highlighted in red and blue. (B) Graphical representation of IFNG 3' UTR in control and ARE-Del T cells, and gel analysis of PCR-amplified IFNG 3'UTR from cDNA generated in the presence $(+)$ or 
absence (-) of SuperScript Reverse Transcriptase (SST) III from DNAse treated nucleotide content from control and ARE-Del T cells.

\section{Supplemental Figure 3 - TNF- $\alpha$ and IL-2 mRNA and protein levels are not altered upon} IFNG ARE-deletion

(A) Rested T cells (9 days) were left untreated or restimulated for $3 \mathrm{~h}$ with $\alpha-C D 3 / \alpha-C D 28$. TNFA and IL2 mRNA levels from $\mathrm{N}=6$ donors from 2 independent experiments (paired Student's t-test; ns, not significant). (B and $\mathbf{C}$ ) Resting T cells were restimulated with $\alpha$-CD3/ $\alpha$ CD28 for 6h. Brefeldin A was added during the last $2 \mathrm{~h}$ of stimulation. (B) Representative dot plots of TNF- $\alpha$ and IL-2 production of live $\mathrm{CD}^{+}$and $\mathrm{CD}^{+}{ }^{+}$T cells. (C) Compiled data on TNF$\alpha^{+}$and IL- $2^{+}$cells from $\mathrm{N}=8$ donors from 4 independent experiments (paired Student's t-test; ns, not significant). T cells cultured in the absence of stimuli were used as negative control. (D) Resting T cells were restimulated for $72 \mathrm{~h}$ with $\alpha-\mathrm{CD} 3 / \alpha-\mathrm{CD} 28$ and removed from stimulus for indicated time. TNF- $\alpha$ and IL-2 protein production was assessed by adding Brefeldin A $4 \mathrm{~h}$ prior to protein production assessment. Representative dot plots of live $\mathrm{CD}^{+}$and $\mathrm{CD} 4^{+} \mathrm{T}$ cells from $\mathrm{n}=7$ donors from 3 independent experiments. $\mathrm{T}$ cells cultured in the absence of stimuli were used as negative control. (E) ARE-deletion in MART-1 TCR-engineered T cells was analyzed by genomic PCR and subsequent gel analysis. 


\section{TABLES}

Table 1 - Primers used in this study

\begin{tabular}{|l|l|}
\hline Name & Sequence (5'->3') \\
\hline ARE-Del gRNA 1 & GTGAGACAGTCACAGGATAT \\
\hline ARE-Del gRNA 2 & ATTTAAAATTCAAATATTGC \\
\hline ARE-Del PCR F & TCGAGGTCGAAGAGCATCCC \\
\hline ARE-Del PCR R & CCCATGGGATCTTGCTTAGGT \\
\hline IFNG_3'PCR_F & TCGAGGTCGAAGAGCATCCC \\
\hline IFNG_3'PCR_R & GGAAGCACCAGGCATGAAATC \\
\hline
\end{tabular}


A

\section{IFNG 3' UTR}

gaggucgaagagcaucccaguaa*ugguuguccugccuGCAA UAUUUGAAUUUUAAAUcuaaaucuAUUUAuuaauAUUUAaca uuAUUUAuauggggaauauauuuuuagacucaucaaucaaau aaguAUUUAuaauagcaacuuuuguguaaugaaaaugaauau cuauuaauauauguauuAUUUAuaauuccuAUAUCCUGUGAC UGUCUCACuuaauccuuuguuuucugacuaauuaggcaaggc uaugugaunacaaggcuuuaucu

C

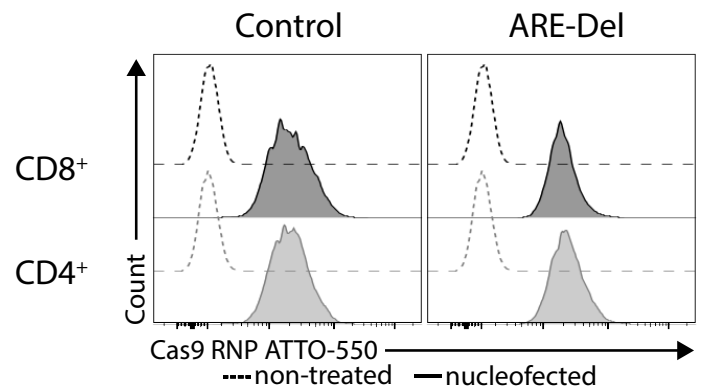

B

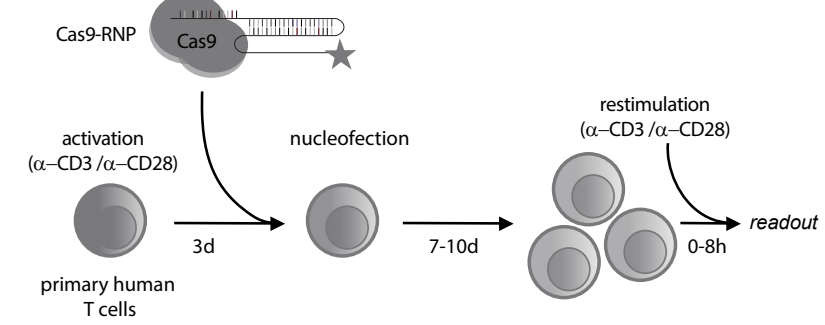

D

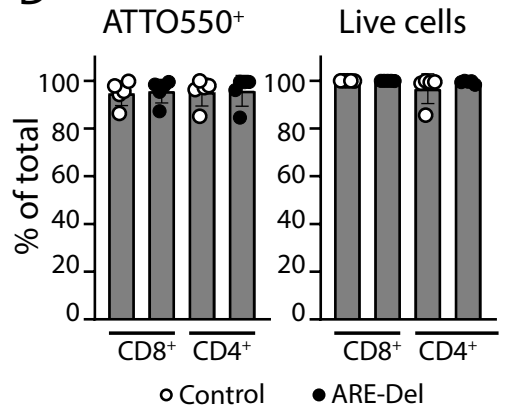

$E$

ARE-Del

WT KO

400

$318 \mathrm{bp} 158 \mathrm{bp}$

100 


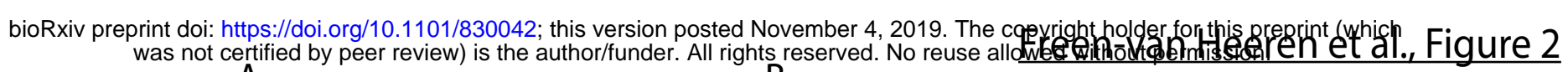
A B
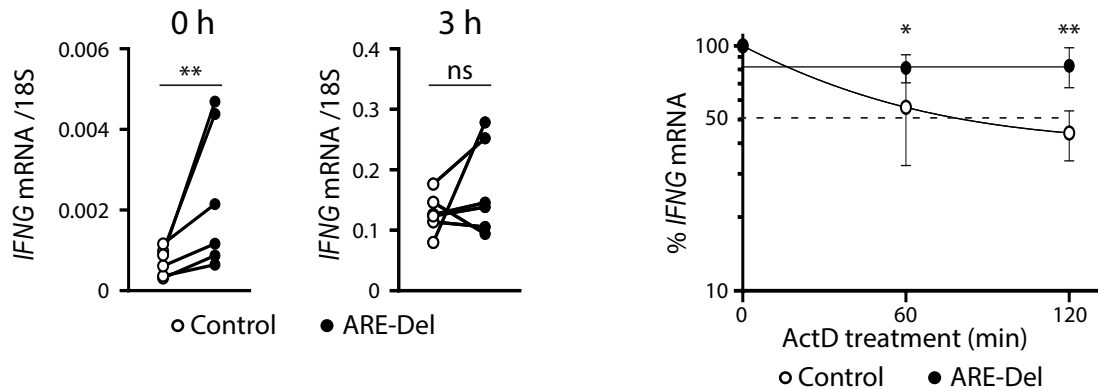

C

\begin{tabular}{|c|c|c|c|c|c|c|c|}
\hline$\alpha-C D 3 / \alpha-C D 28(h)$ & 0 & 1 & 2 & 3 & 4 & 6 & 8 \\
\hline Brefeldin A (h) & 8 & 1 & 2 & 2 & 2 & 2 & 2 \\
\hline
\end{tabular}

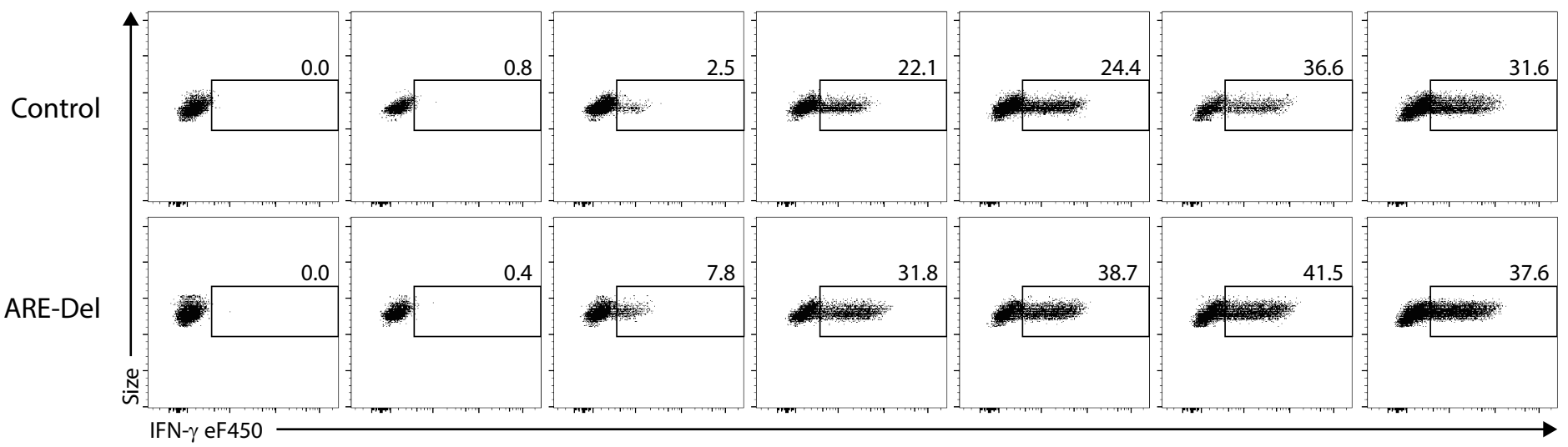


A

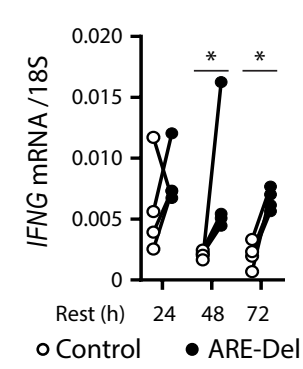

B

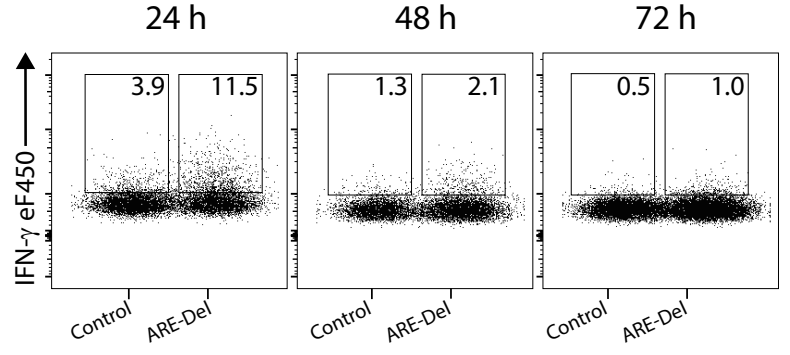

C
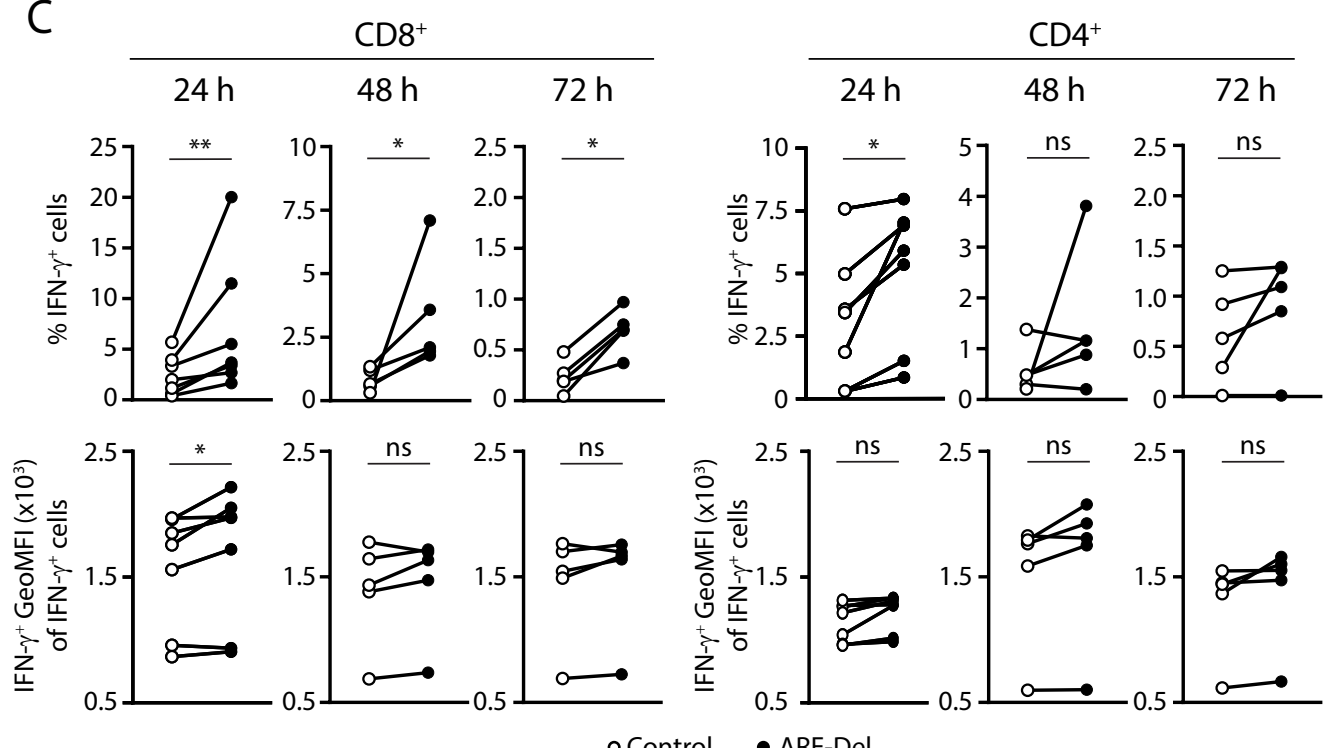$$
\text { - ARE-Del }
$$ 
A

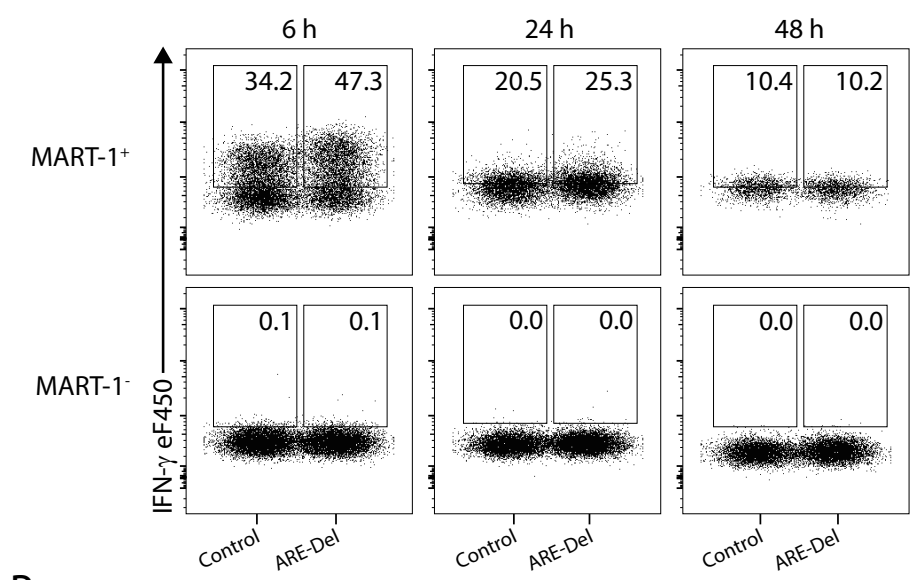

B

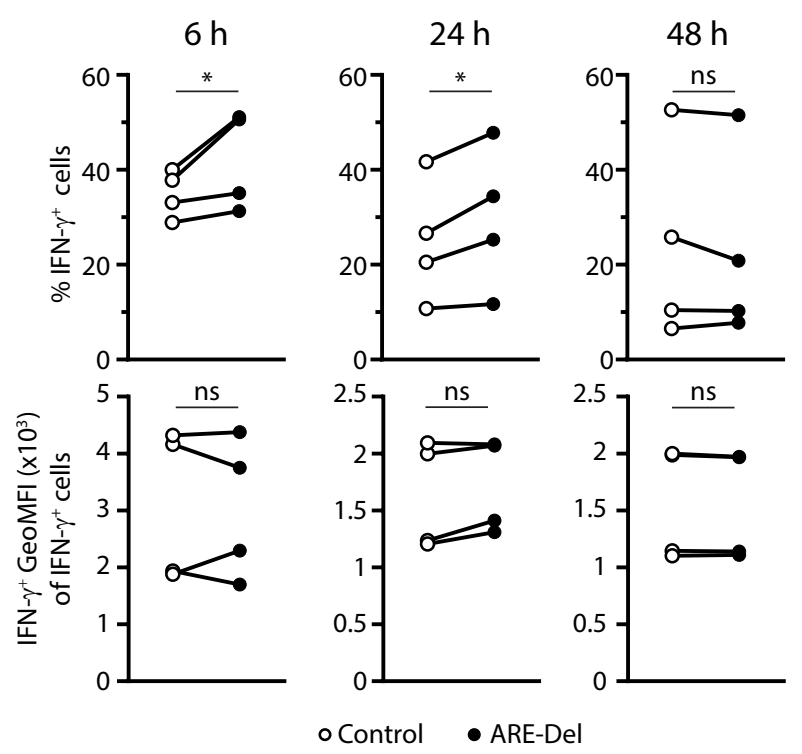


A
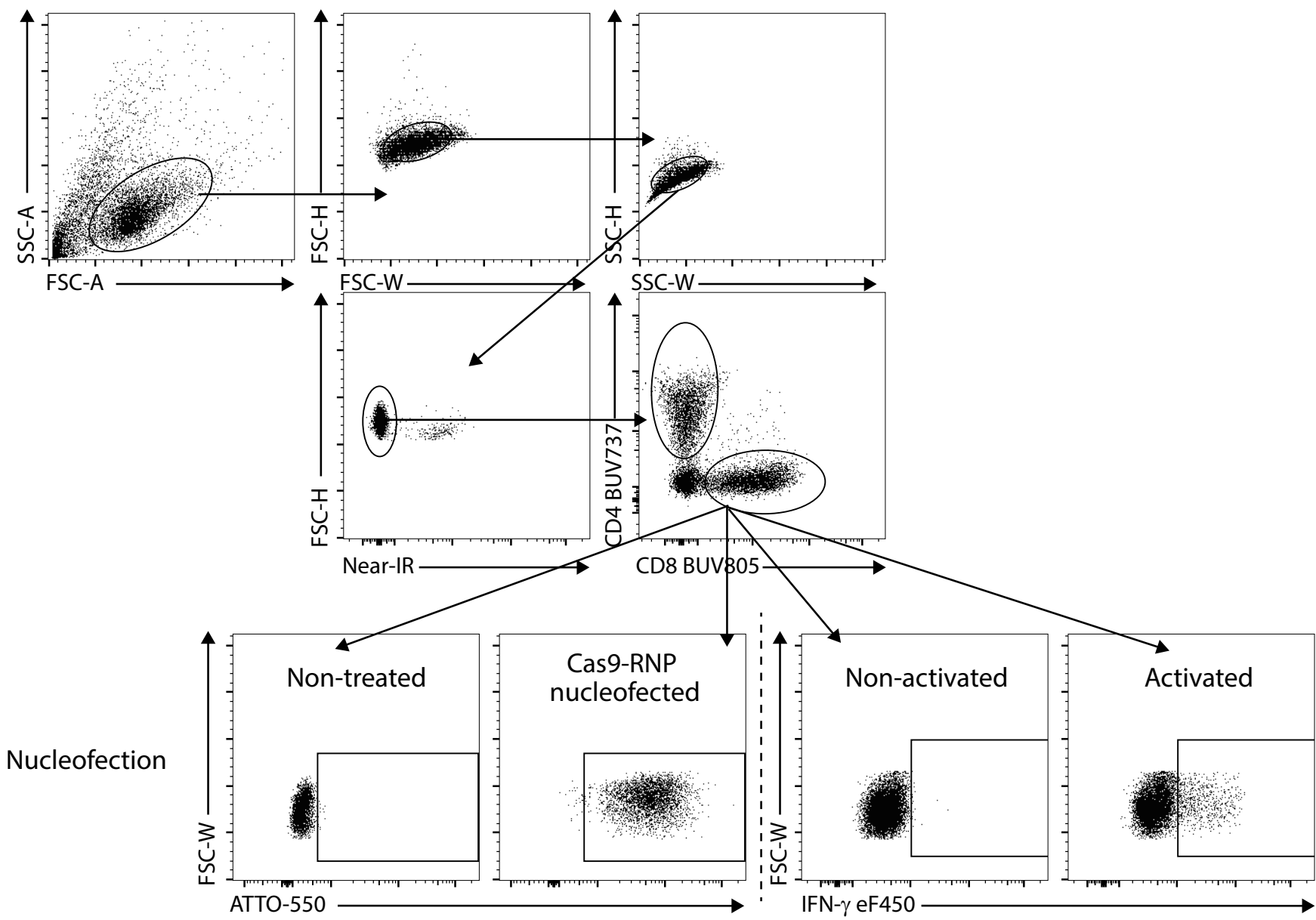

Cytokine production

B

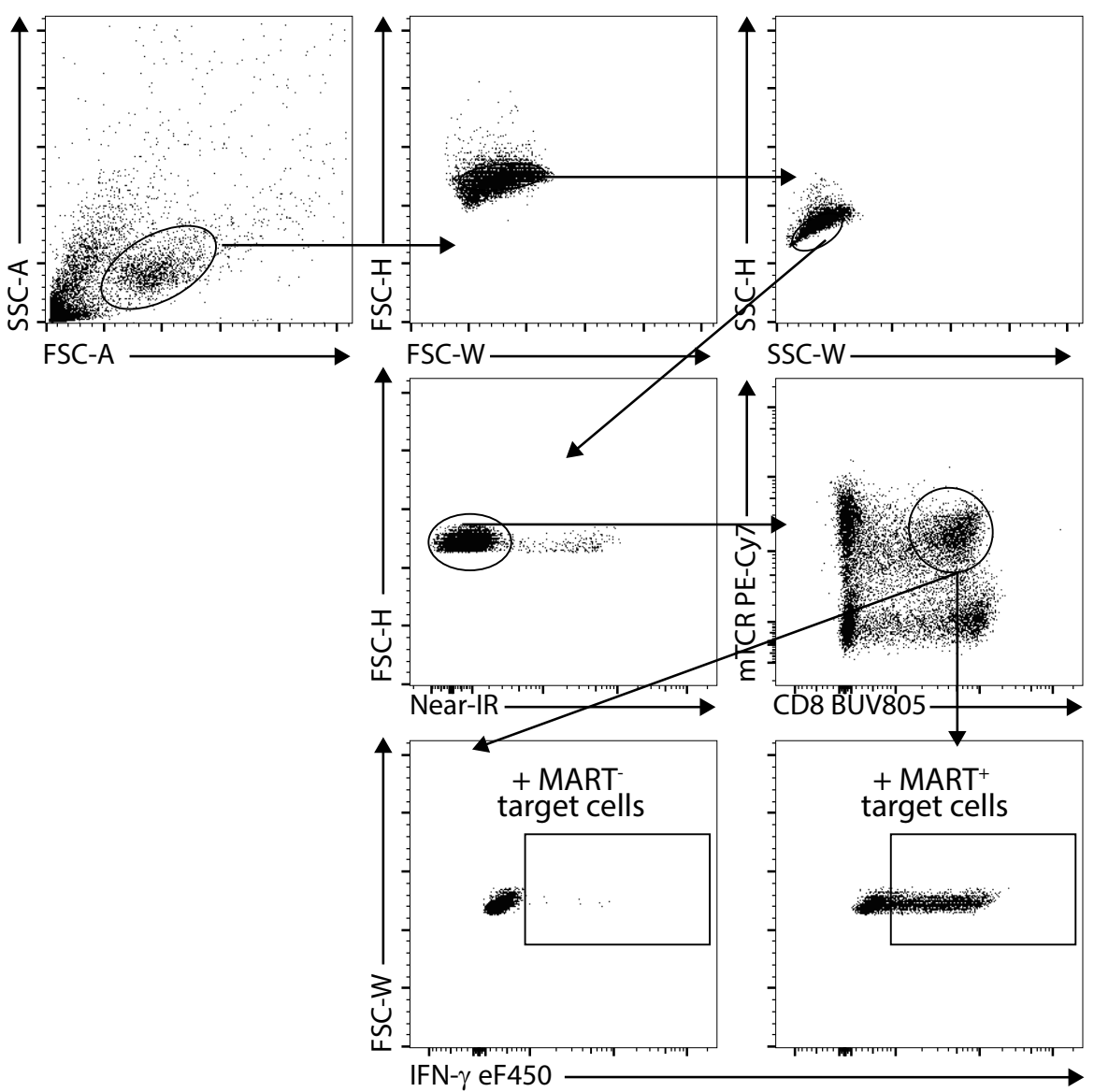


A

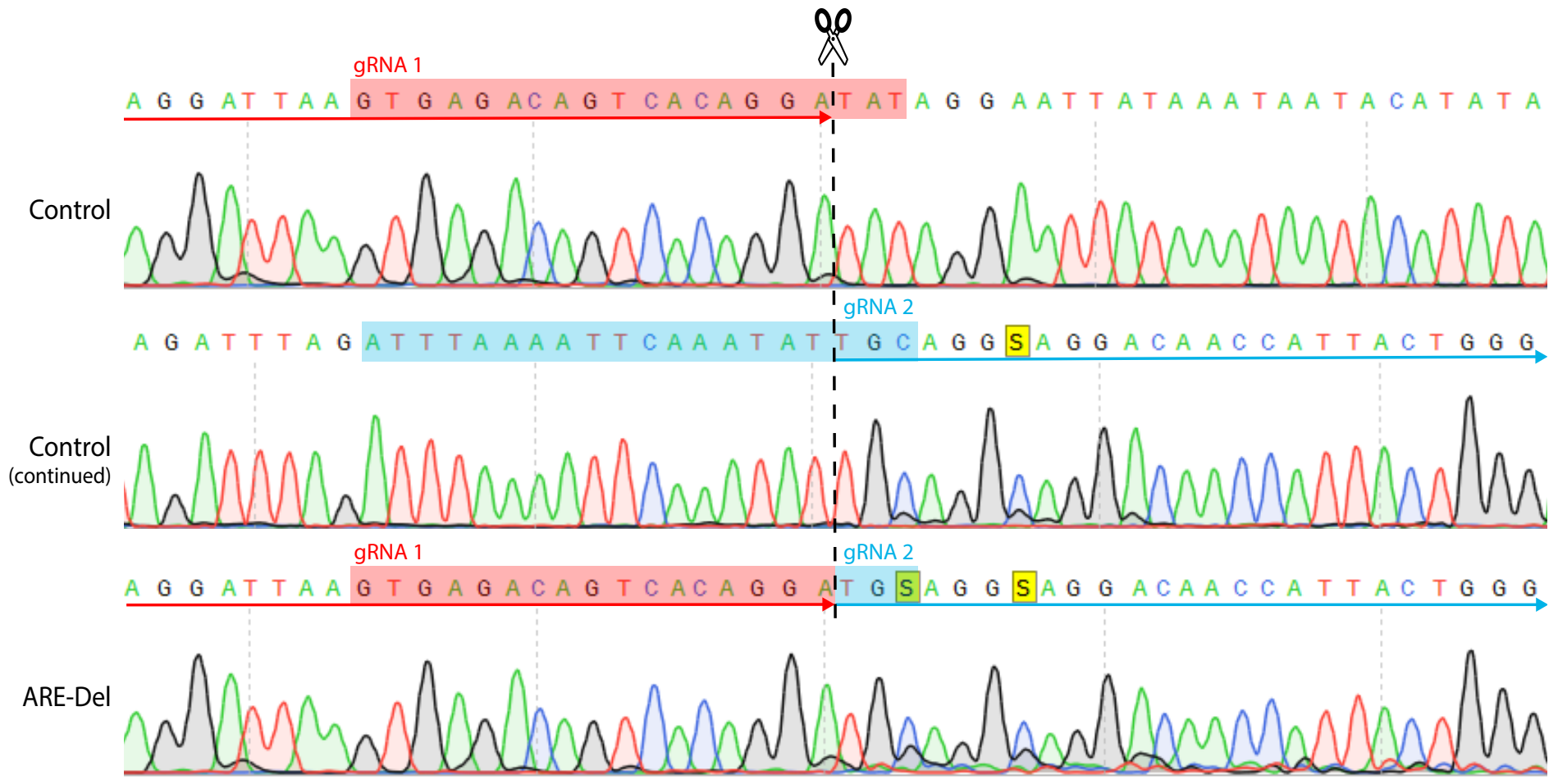

B

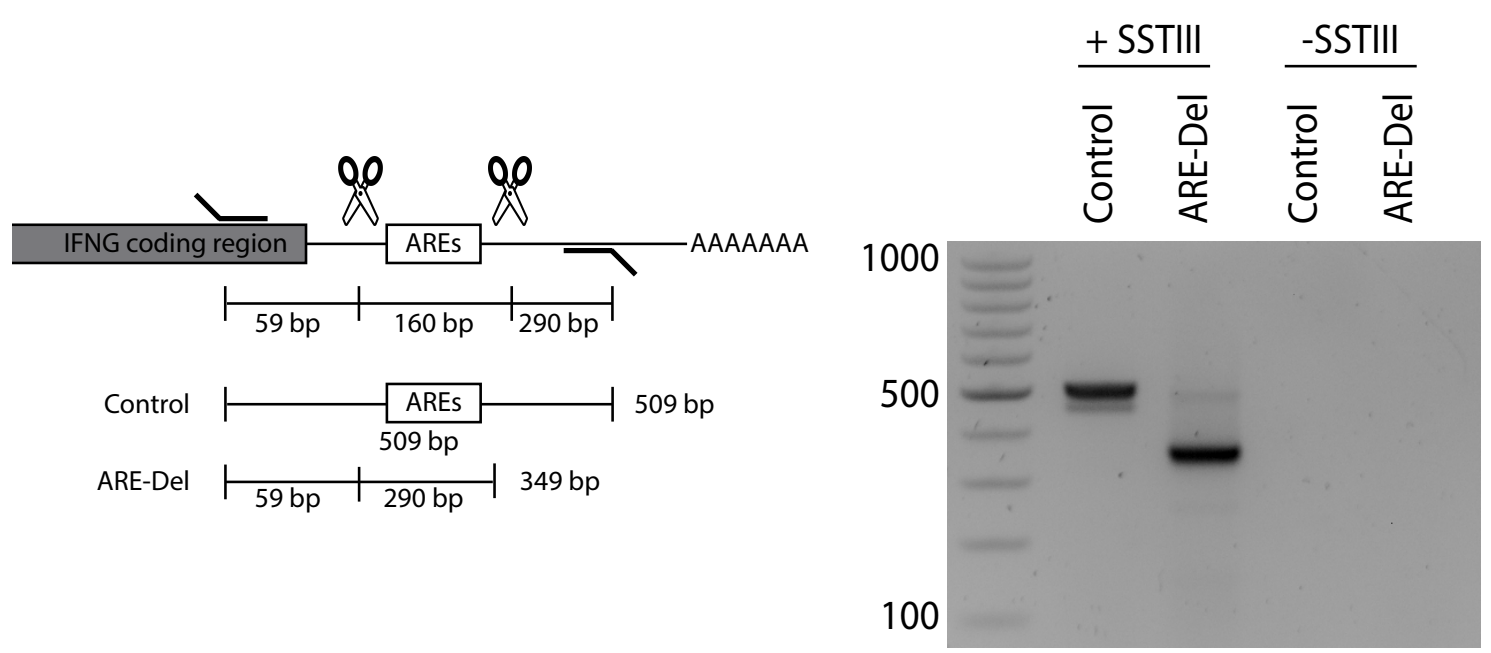


A
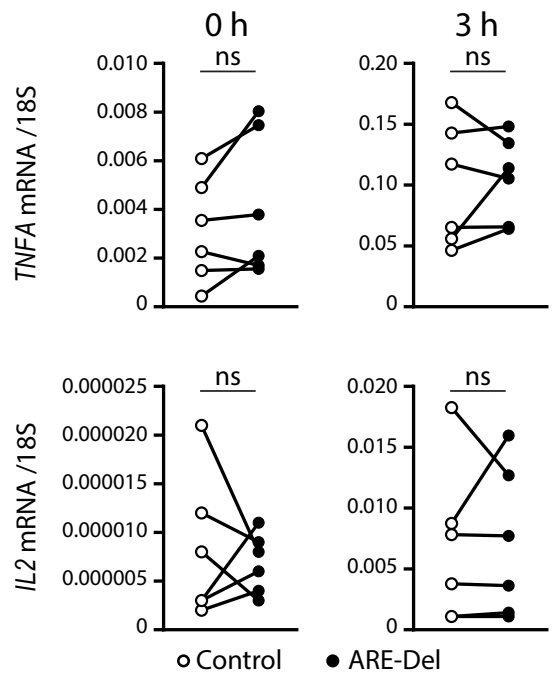

C
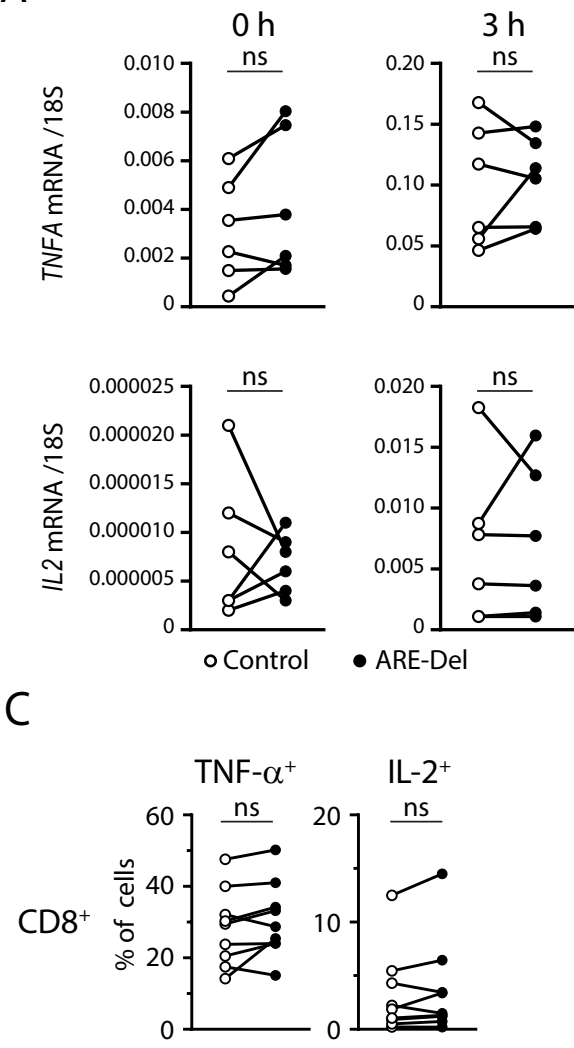

$\mathrm{CD}^{+}+\mathrm{O}_{\text {OControl }}$

E
B $6 \mathrm{~h}$

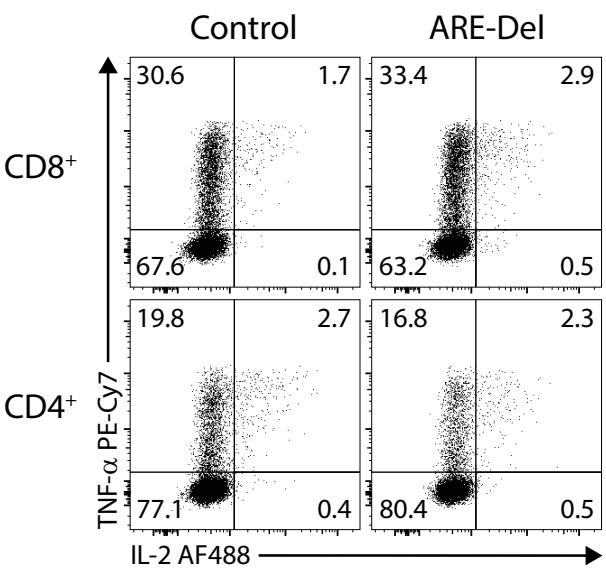

D

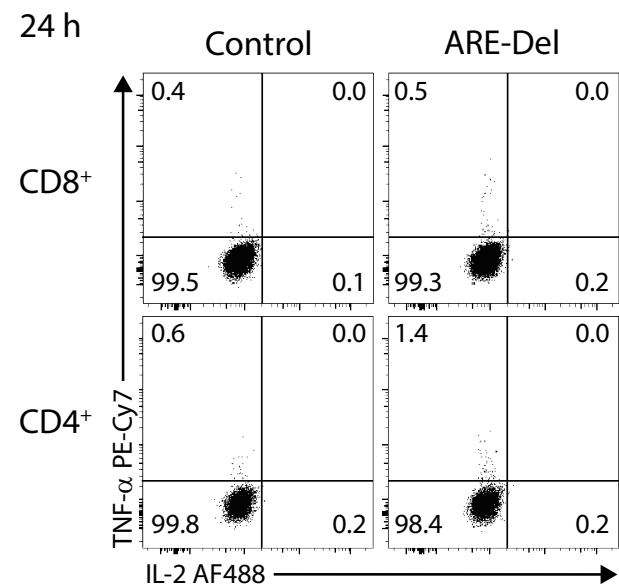

ARE-Del

WT KO $318 \mathrm{bp} 158 \mathrm{bp}$

400

100 